\title{
New methods of nuclear medicine in thyroid
}

Grzegorz Kaminski, $\underline{\text { Affl }}$

Corresponding Affiliation: Aff1

\begin{tabular}{|l|l||l||l||}
\hline \hline \multicolumn{2}{|l||}{ ArticleInfo } \\
\hline \hline ArticleID & $:$ & 202 \\
\hline \hline ArticleDOI & $:$ & $10.1186 / 1756-6614-8-$ S1-A14 \\
\hline \hline ArticleCitationID & $:$ & Al4 \\
\hline \hline ArticleSequenceNumber & $:$ & 14 \\
\hline \hline ArticleCategory & $:$ & Meeting abstract \\
\hline \hline ArticleFirstPage & $:$ & 1 \\
\hline \hline ArticleLastPage & $:$ & 2 \\
\hline \hline ArticleHistory & $:$ & $\begin{array}{l}\text { RegistrationDate } \\
\text { OnlineDate }\end{array}$ \\
\hline \hline & & $\begin{array}{l}\text { Kaminski; licensee BioMed Central Ltd.2015 } \\
\text { This article is published under license to BioMed Central } \\
\text { Ltd. This is an Open Access article distributed under the } \\
\text { terms of the Creative Commons Attribution License } \\
\text { (http://creativecommons.org/licenses/by/4.0), which permits }\end{array}$ \\
\hline ArticleCopyright & $:$ & $\begin{array}{l}\text { unrestricted use, distribution, and reproduction in any } \\
\text { medium, provided the original work is properly cited. The } \\
\text { Creative Commons Public Domain Dedication waiver } \\
\text { http://creativecommons.org/publicdomain/zero/1.0/) applies } \\
\text { to the data made available in this article, unless otherwise } \\
\text { stated. }\end{array}$ \\
\hline
\end{tabular}

Aff1

Military Institute of Medicine, Warsaw, Poland

Spring School of Thyroidology organized by the Polish Thyroid Association 2014: abstracts of invited lectures

Spring School of Thyroidology organized by the Polish Thyroid Association 2014

Miedzyzdroje, Poland

23-24 May 2014

Publication of this supplement was funded by the Polish Thyroid Association. The Supplement Editors declare that they have no competing interests.

Meeting abstracts

Andrzej Lewinski

Mariusz Stasiolek 
Since radioiodine was first introduced in the therapy of hyperthyroidism in the $1940 \mathrm{~s}$, in the $21^{\text {st }}$ century, thyroid has become the arena of development of nuclear-molecular biology imaging. SPECT and PET technics allow the visualization of small particles like peptides and their receptors. In PET with ${ }^{18}$ F-FDG we can assess metabolic activity of thyroid tumours. If there is higher metabolic activity, the tumour is more aggressive and the prognosis poorer. These novel methods let us observe the primary lesion and metastatic processes in iodine avid differentiated thyroid cancer (DTC) and medullary thyroid cancer (MTC). Potentially, each particle triggered with a radioisotope which is involved in a cell structure and/or its metabolism can be useful in molecular imaging. The first group of molecules used in radioisotope molecular imaging is peptide receptors agonists and antagonists. Somatostatin receptors are overexpressed in DTC and MTC. Therefore, somatostatin analogues triggered with radioisotopes are used in either imaging $\left({ }^{99 \mathrm{~m}}\right.$ Technetium, ${ }^{111}$ Indium, ${ }^{68}$ Gallium $)$ or treatment $\left({ }^{90} \mathrm{Yttrium}\right.$, ${ }^{177}$ Lutetium) of these malignancies. Implementation of appropriate chelator allowed the creation of radiopharmaceuticals conjugated with either SPECT or PET isotopes. It seems that the best method for visualization of MTC is PET with ${ }^{18} \mathrm{~F}$-DOPA up till now. Recently, new radiolabelled tracers for MTC visualizations are under investigation: cholecystokinin - 2 (CKK-2) gastrin receptor ligand radiolabelled with

${ }^{111}$ Indium and glucagon - like peptide $-1(\mathrm{GLP}-1)$ labelled with ${ }^{99 \mathrm{~m}}$ Technetium.

\section{References}

1. Pepe G, Moncayo R, Bombardieri E, Chiti A: Somatostatin receptor SPECT. Eur J Nucl Med Mol Imaging 2012,39(Suppl 1):S41-S51.

2. Wild D, Fani M, Behe M, Brink I, Rivier JE, Reubi JC, et al.: First clinical evidence that imaging with somatostatin receptor antagonists is feasible. $J$ Nucl Med 2011,52(9):1412-1417. 10.2967/jnumed.111.088922

3. Wang X, Fani M, Schulz S, Rivier J, Reubi JC, Maecke HR: Comprehensive evaluation of a somatostatin-based radiolabelled antagonist for diagnostic imaging and radionuclide therapy. Eur $J$ Nucl Med Mol Imaging 2012,39(12):1876-1885. 10.1007/s00259-012-2231-8

4. Ambrosini V, Fani M, Fanti S, Forrer F, Maecke HR: Radiopeptide Imaging and Therapy in Europe. $J$ Nucl Med 2011,52(Suppl 2):42S-55S.

5. Fani M, Maecke HR, Okavi SM: Radiolabeled peptides: Valuable tools for the detection and treatment of cancer. Theranostics 2012,2(5):481-501. 10.7150/thno.4024

6. Pach D, Sowa-Staszczak A, Jabrocka-Hybel A, Stefańska A, Tomaszuk M, Mikołajczak R, et al.: Glucagon-like peptide-1 Receptor Imaging with [Lys Ahx-HYNIC- 99mTc(EDDA)NH2]-Exendin- 4 for the medullary Thyroid Cancer. Int J Endocrinol 2013, 2013: 481-501. 